Int. J. Electrochem. Sci., 14 (2019) $4580-4594$

International Journal of

ELECTROCHEMICAL

SCIENCE

$\underline{\text { WwW.electrochemsci.org }}$

\title{
Influence of Constant Current Accelerated Corrosion on the Bond Properties of Reinforced Concrete
}

\author{
Yang Sun ${ }^{l}$, Guofu Qiao $^{1,2^{*}}$ \\ ${ }^{1}$ School of Civil Engineering, Harbin Institute of Technology, Harbin, 150090, China \\ ${ }^{2}$ Key Lab of Structures Dynamic Behavior and Control (Harbin Institute of Technology), Ministry of \\ Education, Harbin, 150090, China \\ "E-mail: qgf_forever@hit.edu.cn qgfhit@163.com
}

doi: $10.20964 / 2019.05 .36$

Received: 9 January 2019 / Accepted: 5 March 2019 / Published: 10 April 2019

\begin{abstract}
Reinforcement corrosion is one of the most serious durability problems faced by reinforced concrete (RC) structures. In the laboratory, current accelerated corrosion method is widely used to corrode RC structures. In order to reduce the experimental time, high current density always tends to be adopted in the experiments, but the effects of current on the mechanical properties of RC structures are neglected. In this study, four groups of RC members were corroded by current accelerated corrosion method, and the impressed constant current densities were $200 \mu \mathrm{A} / \mathrm{cm}^{2}, 400 \mu \mathrm{A} / \mathrm{cm}^{2}, 600 \mu \mathrm{A} / \mathrm{cm}^{2}$ and $1000 \mu \mathrm{A} / \mathrm{cm}^{2}$ respectively. The crack width of concrete and its corresponding power time were recorded in the accelerated corrosion process. After corrosion, the pull-out tests were performed to get the bond strengths of corroded RC members. The experimental results obtained indicate that increasing the magnitude of the impressed current density results in a significant increase in maximum crack width. In the attenuation model of bond strength, with the increase of impressed current, the critical corrosion level seems to decrease and the bond strength decreases sharply with the corrosion level.
\end{abstract}

Keywords: Corrosion; Current density; Crack width; Bond strength; Critical corrosion level

\section{$\underline{\text { FULL TEXT }}$}

(C) 2019 The Authors. Published by ESG (www.electrochemsci.org). This article is an open access article distributed under the terms and conditions of the Creative Commons Attribution license (http://creativecommons.org/licenses/by/4.0/). 